\title{
Cytomorphology of some species of the angiosperm from Kangra District, H.P., India
}

\author{
Kuljit Kaur ${ }^{1}$, Raghbir Chand Gupta and Santosh Kumari \\ Department of Botany, Punjabi University, Patiala, Punjab 147002, India \\ ${ }^{1}$ Author for Correspondence: kuljitkajla88@gmail.com \\ Received October 1, 2013; accepted December 2, 2013
}

\begin{abstract}
Male meiosis and pollen fertility have been studied in 31 angiospermic species belonging to 29 genera and eight families. During meiotic course, ten species are found to have anomalous meiotic course exhibiting the abnormalities in varying frequencies as Capillipedium assimile (chromatin stickiness, cytomixis), Phacelurus speciosus (chromatin stickiness, laggards, bridges, unoriented bivalents), Lolium remotum (cytomixis, laggards, bridges, micronuclei), Sisymbrium strictum (cytomixis, laggards, bridges), Ranunculus hyperboreus (cytomixis, laggards, bridges, micronuclei), Impatiens scabrida (laggards, bridges and abnormal microsporogenesis), Pennisetum alopecuroides (laggards and bridges), Phalaris minor (laggards, bridges, unoriented bivalents), Dactylis glomerata (late disjunction of bivalents). These abnormalities results in the reduction of pollen fertility of the plants.
\end{abstract}

KEYWORDS: Chromosome abnormalities, Kangra, Pollen meiosis

Kangra is one of the most picturesque valley which is situated on the South Western end of H.P., a hilly state of Western Himalayas. The geographical area of the district is $5,739 \mathrm{~km}^{2}$ and lies between the range of North latitude $31^{\circ} 45^{\prime} 0$ " to $32^{\circ} 28^{\prime} 5^{\prime \prime}$ " and East longitude $75^{\circ} 35^{\prime} 34^{\prime \prime}$ to $74^{\circ} 04^{\prime} 46^{\prime \prime}$. Its area extends from low hills sub-tropical zone of altitude range (400-650 m) in Shiwalik to high hill wet sub-temperate zone (above $1800 \mathrm{~m}$ ) in Dhauladhar and Pir Punjal through mid-hill sub-humid zone (650$1800 \mathrm{~m})$ in Palampur and Dharamshala. The district has generally light textured, neutral $\mathrm{pH}$ with good fertility status. The temperature fluctuation for different areas also varies from extremely low to moderately low as from $0^{\circ} \mathrm{C}$ to $20^{\circ} \mathrm{C}$ during winter and reaches upto $35^{\circ} \mathrm{C}$ during summer. Annual rainfall ranges between 900-3000 mm annually. Kangra district rich in flora, consisting of variable type of vegetation as from scrub forest at low elevation (600-1200 m) to alpine pasture at higher altitude (above $3800 \mathrm{~m}$ ). Notable studies regarding distribution of medicinal and aromatic plants of the area were made by some workers such as Ahluwalia (1952) from Kangra, Uniyal and Chauhan $(1971,1973)$ from in and around Kangra, Sood et al. (1982) from Palampur, Kapur (1993) from Kangra Valley, Sharma and Maheshwari (2005) from Kangra District and Uniyal et al. (2006) from Chotta Bhangal Area of Kangra District.

\section{Materials and Methods}

For meiotic studies, young flower buds/panicles/ spikes of appropriate size were collected from wild plants during the peak period of flowering growing in the different localities of district Kangra (Himachal Pradesh). The flowers buds were then fixed in freshly prepared Carnoy's fixative (6 ethanol: 3 chloroform: 1 acetic acid) for $24 \mathrm{hrs}$. Subsequently the materials were transferred to $70 \%$ ethyl alcohol and stored in refrigerator. For pollen mother cells preparation, the developing anthers were squashed in
$1 \%$ acetocarmine. A number of freshly prepared slides were carefully examined for detailed meiotic course and chromosome counts. Images of chromosome counts, meiotic course and pollen grains were photomicrographed from the freshly prepared slides with a "Nikon 80 i digital imaging system". Pollen fertility in each taxon was estimated by stainability of pollen grains in glyceroacetocarmine (1:1) mixture and subsequently kept for 24 hrs. The pollen grains filled with stained nuclei were taken as fertile and those with unstained cytoplasm and shriveled nuclei taken as sterile. Pollen grain size was measured using an occulometer. Voucher specimens of the species are deposited in the Herbarium, department of Botany, Punjabi University, Patiala (PUN), India and accession numbers are given in Table 1.

\section{Results And Discussion}

FAMILY BALSAMINACEAE Impatiens scabrida DC.: It is an annual herb with erect pubescent stem, leaves alternate elliptical and yellow coloured axillary flowers. The present species has been collected from Chhota Bhangal situated at an altitude of $2,300 \mathrm{~m}$. The meiotic course of the species shows 6 bivalents which is in conformity with the earlier reports of $2 \mathrm{n}=12$ (Jeelani et al. 2011). The species is found to have abnormal meiotic course with the presence of various meiotic abnormalities as unoriented bivalents at metaphase I (4.6\%), bridges at anaphase I (2.8\%), resulting into abnormal microsporogenesis and heterogenous sized pollen grains along with reduced pollen fertility (63.91\%).

FAMILY BRASSICACEAE Sisymbrium strictum Phil.: It is a pubescent herb with pale-pink coloured flowers and curved pods. At present, collection has been made from Baragran located at an altitude of 3,000 m. Meiotic course of the species depicts the presence of 7 bivalents at metaphase I. The present diploid cytotype is in conformity 
Table 1. Information on Taxa with accession number, habit, locality with altitude, meiotic chromosome numbers, ploidy level, meiotic course, pollen fertility, average pollen size of the investigated flowering plants from district Kangra of Himachal Pradesh.

\begin{tabular}{|c|c|c|c|c|c|c|c|}
\hline $\begin{array}{l}\text { Sr. } \\
\text { No. }\end{array}$ & $\begin{array}{l}\text { Taxon* } \\
\text { (Accession number --PUN) }\end{array}$ & Habit & $\begin{array}{l}\text { Locality with } \\
\text { Altitude (m) }\end{array}$ & $\begin{array}{l}\text { Meiotic } \\
\text { Chromosome } \\
\text { Number (n) }\end{array}$ & $\begin{array}{l}\text { Ploidy } \\
\text { Level/ } \\
\text { Meiotic } \\
\text { course** }\end{array}$ & $\begin{array}{l}\text { Pollen } \\
\text { Fertiliy } \\
(\%)\end{array}$ & $\begin{array}{l}\text { Pollen size } \\
(\mu \mathrm{m})\end{array}$ \\
\hline \multicolumn{8}{|c|}{ FAMILY:BALSAMINACEAE } \\
\hline 1. & $\begin{array}{l}\text { Impatiens scabrida DC. } \\
(55623)\end{array}$ & Herb & $\begin{array}{l}\text { Chhota Bhangal, } \\
2,300\end{array}$ & $n=6$ & $2 \mathrm{x} / \mathrm{A}$ & 63.91 & $\begin{array}{l}32.98 \times 19.05- \\
34.75 \times 21.76\end{array}$ \\
\hline \multicolumn{8}{|c|}{ FAMILY: BRASSICACEAE } \\
\hline 2. & $\begin{array}{l}\text { Sisymbrium strictum Phil. } \\
(55622)\end{array}$ & Herb & Baragran, 3,000 & $n=7$ & $2 \mathrm{x} / \mathrm{A}$ & 62.78 & $\begin{array}{l}14.56 \times 13.26- \\
16.75 \times 15.90\end{array}$ \\
\hline \multicolumn{8}{|c|}{ FAMILY: FABACEAE } \\
\hline 3. & $\begin{array}{l}\text { Aeschynomene indica Wall. } \\
(55618)\end{array}$ & Herb & Ranhear, 850 & $\mathrm{n}=20$ & $2 \mathrm{x} / \mathrm{N}$ & 98.70 & $17.92 \times 16.48$ \\
\hline 4. & $\begin{array}{l}\text { Desmodium gangeticum (L.) } \\
\text { DC. } \\
(55621)\end{array}$ & Herb & Boh, 1,900 & $\mathrm{n}=11$ & $2 \mathrm{x} / \mathrm{N}$ & 91.00 & $22.26 \times 21.82$ \\
\hline 5. & $\begin{array}{l}\text { Lathyrus aphaca L. } \\
(55627)\end{array}$ & Herb & Puharda, 700 & $n=7$ & $2 \mathrm{x} / \mathrm{N}$ & 97.53 & $42.50 \times 37.22$ \\
\hline 6. & $\begin{array}{l}\text { Vicia bithynica } \mathrm{L} . \\
(55615)\end{array}$ & Herb & Boh, 1,900 & $n=7$ & $2 \mathrm{x} / \mathrm{N}$ & 95.70 & $30.67 \times 28.78$ \\
\hline 7. & $\begin{array}{l}\text { Vicia hirsuta (L.) Gray } \\
(55628)\end{array}$ & Herb & Rait, 700 & $n=6$ & $2 \mathrm{x} / \mathrm{N}$ & 98.42 & $29.80 \times 33.81$ \\
\hline 8. & $\begin{array}{l}\text { Vicia tetrasperma }(\text { L.) Schreb } \\
(55629)\end{array}$ & Herb & Ranhear, 850 & $n=7$ & $2 \mathrm{x} / \mathrm{N}$ & 98.80 & $33.12 \times 28.75$ \\
\hline \multicolumn{8}{|c|}{ FAMILY: MALVACEAE } \\
\hline 9. & $\begin{array}{l}\text { Malvastrum coromendelianum } \\
\text { (L.) Garcke } \\
\text { ( 55619) }\end{array}$ & Herb & Rehlu, 800 & $\mathrm{n}=12$ & $2 \mathrm{x} / \mathrm{N}$ & 92.30 & $40.43 \times 35.09$ \\
\hline 10. & $\begin{array}{l}\text { Malva neglecta } \\
\text { Wallr. (= Malva verticillata } \text { L.) } \\
(55620)\end{array}$ & Herb & Suliali, 1,400 & $n=21+$ & $6 \mathrm{x} / \mathrm{N}$ & 93.00 & $39.30 \times 35.41$ \\
\hline \multicolumn{8}{|c|}{ FAMILY: ONAGRACEAE } \\
\hline 11. & $\begin{array}{l}\text { Epilobium alpinum Griseb. } \\
(55625)\end{array}$ & Herb & Bara gran, 3,000 & $\mathrm{n}=18$ & $2 \mathrm{x} / \mathrm{N}$ & 91.20 & $24.12 \times 22.16$ \\
\hline \multicolumn{8}{|c|}{ Family: Poaceae } \\
\hline 12. & \begin{tabular}{|l|} 
Alopecurus nepalensis Trin. Ex \\
Steud. \\
$(55725)$
\end{tabular} & Herb & Pohara, 800 & $\mathrm{n}=21$ & $6 x / N$ & 94.67 & $33.81 \times 32.48$ \\
\hline 13. & $\begin{array}{l}\text { Capillipedium assimile } \mathrm{A} . \\
\text { Camus } \\
(55719)\end{array}$ & Herb & Palampur, 2,000 & $\mathrm{n}=10$ & $2 \mathrm{x} / \mathrm{A}$ & 69.30 & $\begin{array}{l}23.39 \times 22.76- \\
25.67 \times 23.98\end{array}$ \\
\hline 14. & $\begin{array}{l}\text { Dactylis glomerata L. } \\
(55727)\end{array}$ & Herb & $\begin{array}{l}\text { Lohardhari, } \\
2,600\end{array}$ & $\mathrm{n}=7$ & $2 \mathrm{x} / \mathrm{A}$ & 73.67 & $\begin{array}{l}20.24 \times 17.45- \\
22.53 \times 20.67\end{array}$ \\
\hline 15. & $\begin{array}{l}\text { Dichanthium annulatum Stapf } \\
(55722)\end{array}$ & Herb & Andretta, 1,200 & $\mathrm{n}=20$ & $4 \mathrm{x} / \mathrm{A}$ & 67.54 & \begin{tabular}{|l|}
$36.31 \times 32.37-$ \\
$39.76 \times 35.97$
\end{tabular} \\
\hline 16. & $\begin{array}{l}\text { Digitaria adscendens Henrard } \\
(\mathrm{GCl}) \\
(55724)\end{array}$ & Herb & Ranhear, 850 & $n=36$ & $8 \mathrm{x} / \mathrm{N}$ & 94.32 & $\begin{array}{l}30.53 \times 28.02- \\
34.86 \times 30.85\end{array}$ \\
\hline 17. & $\begin{array}{l}\text { Eleusine indica (L.) Gaertn. } \\
(55720)\end{array}$ & Herb & $\begin{array}{l}\text { Macleodganj, } \\
1,900\end{array}$ & $n=9$ & $2 \mathrm{x} / \mathrm{N}$ & 92.10 & $20.20 \times 18.28$ \\
\hline 18. & $\begin{array}{l}\text { Koeleria macrantha (Ledeb.) } \\
\text { Schult. } \\
(00000)\end{array}$ & Herb & Lohardhari & $\mathrm{n}=7$ & $2 \mathrm{x} / \mathrm{N}$ & 98.45 & $25.66 \times 22.65$ \\
\hline 19. & $\begin{array}{l}\text { Lolium remotum Schrank } \\
(52855)\end{array}$ & Herb & Bada gran, 3,000 & $n=7$ & $2 \mathrm{x} / \mathrm{A}$ & 65.20 & \begin{tabular}{|l|}
$32.85 \times 31.86-$ \\
$34.42 \times 32.94$
\end{tabular} \\
\hline 20. & $\begin{array}{l}\text { Pennisetum alopecuroides } \\
\text { Spreng. } \\
(55718)\end{array}$ & Herb & Daadh, 1,400 & $\mathrm{n}=18$ & $4 \mathrm{x} / \mathrm{A}$ & 75.20 & $\begin{array}{l}34.44 \times 32.28 \\
37.65 \times 35.34\end{array}$ \\
\hline 21. & $\begin{array}{l}\text { Phacelurus speciosus } \\
\text { C.E.Hubb. } \\
(55727)\end{array}$ & Herb & $\begin{array}{l}\text { Lohardhari, } \\
2,600\end{array}$ & $\mathrm{n}=30$ & $6 x / A$ & 67.80 & $\begin{array}{l}41.66 \times 40.64- \\
45.73 \times 43.51\end{array}$ \\
\hline
\end{tabular}




\begin{tabular}{|c|c|c|c|c|c|c|c|}
\hline 22. & $\begin{array}{l}\text { Phalaris minor Retz. } \\
(55730)\end{array}$ & Herb & Bandla, 1,600 & $\mathrm{n}=14$ & $4 \mathrm{x} / \mathrm{A}$ & 77.13 & $\begin{array}{l}33.86 \times 30.15- \\
38.26 \times 35.86\end{array}$ \\
\hline 23. & $\begin{array}{l}\text { Poa annua } \mathrm{L} . \\
(55729)\end{array}$ & Herb & Jawala Ji, 550 & $\mathrm{n}=14$ & $4 \mathrm{x} / \mathrm{N}$ & 98.00 & $29.66 \times 27.66$ \\
\hline 24. & $\begin{array}{l}\text { Pogonatherum crinitum Kunth } \\
(55721)\end{array}$ & Herb & Nagrota, 900 & $\mathrm{n}=10$ & $2 \mathrm{x} / \mathrm{N}$ & 91.50 & $21.18 \times 19.15$ \\
\hline 25. & $\begin{array}{l}\text { Polypogon monspeliensis (L.) } \\
\text { Desf. } \\
(55726)\end{array}$ & Herb & Bandla, 1,600 & $\mathrm{n}=21$ & $6 \mathrm{x} / \mathrm{N}$ & 94.87 & $30.40 \times 28.02$ \\
\hline 26. & $\begin{array}{l}\text { Setaria glauca Kunth } \\
(55716)\end{array}$ & Herb & Dehra, 550 & $\mathrm{n}=18$ & $4 \mathrm{x} / \mathrm{N}$ & 96.90 & $28.53 \times 27.16$ \\
\hline 27. & $\begin{array}{l}\text { Setaria tomentosa Kunth } \\
(55717)\end{array}$ & Herb & $\begin{array}{l}\text { Dharamshala, } \\
1,800\end{array}$ & $\mathrm{n}=18$ & $4 \mathrm{x} / \mathrm{N}$ & 91.55 & $26.36 \times 24.49$ \\
\hline \multicolumn{8}{|c|}{ FAMILY: RANUNCULACEAE } \\
\hline 28. & $\begin{array}{l}\text { Ranunculus hyperboreus Rottb. } \\
(55616)\end{array}$ & Herb & Multan, 2,300 & $\mathrm{n}=14$ & $4 \mathrm{x} / \mathrm{A}$ & 62.78 & $28.70 \times 28.50$ \\
\hline \multicolumn{8}{|c|}{ FAMILY: ROSACEAE } \\
\hline 29. & $\begin{array}{l}\text { Pyrus pashia } \text { Buch.-Ham.ex } \\
\text { D.Don } \\
(55617)\end{array}$ & Tree & Multan, 2,300 & $\mathrm{n}=17$ & $2 \mathrm{x} / \mathrm{N}$ & 82.00 & $24.58 \times 22.40$ \\
\hline 30. & $\begin{array}{l}\text { Rosa macrophylla Lindl. } \\
(55626)\end{array}$ & Shrub & Ranhear, 850 & $\mathrm{n}=7$ & $2 \mathrm{x} / \mathrm{N}$ & 92.40 & $20.33 \times 19.69$ \\
\hline 31. & $\begin{array}{l}\text { Rubus ellipticus Sm. } \\
(52861)\end{array}$ & Shrub & Ranhear, 850 & $\mathrm{n}=7$ & $2 \mathrm{x} / \mathrm{N}$ & 80.22 & $22.80 \times 20.36$ \\
\hline
\end{tabular}

* Families(Poaceae is only one family belonging to the Monocots), Genera and Species, all are arranged alphabetically for convenience sake.

**A= Abnormal, $\mathrm{N}=$ Normal

with the previous reports from India and outside India (Jaretzky, 1932). Subsequent course of meiosis is abnormal with the presence of laggards at telophase I $(9.68 \%)$, bridge at anaphase I $(3.86 \%)$, cytomixis at telophase II $(5.4 \%)$ and all these abnormalities leads to reduced pollen fertility $(62.78 \%)$.

FAMILY: FABACEAE Aeschynomene indica L.: It is an annual herb with glabrous stem which grows as weed in paddy fields. The leaves are imparipinnate and flowers are yellow coloured with purple veins. The pod is jointed, smooth and nearly straight. The species has been collected from Ranhear located at an altitude of $850 \mathrm{~m}$. The chromosome in presently studied species is confirmed from presence of seven bivalents at metaphase I. The present chromosome count of $\mathrm{n}=7$ confirms to the previous reports of $2 \mathrm{n}=14$ from India (Sidhu and Bir 1983, Bairiganjan and Patnaik 1989) and outside India. The course of meiosis has been found to be normal with high pollen fertility $(98.70 \%)$.

Desmodium gangeticum (L.) DC.: It is an erect perennial herb and leaves are one foliolate with ovate-oblong leaflet. The flowers are densely hairy and terminal in axillary racemes. The presently studied species has been collected from Boh at $1900 \mathrm{~m}$ altitude. The meiotic course of the species depicts the presence of 11 bivalents at metaphase I. The course of meiosis is normal and shows high pollen fertility $(91.0 \%)$. The present report of $n=11$ is in conformity with the previous reports of $2 n=22$ from India (Kumari and Bir 1990) and outside India.
Lathyrus aphaca $L .:$ It is an annual trailing herb with glabrous stem. Flowers are yellow coloured in axillary raceme. Pod is glabrous, 4-6 seeded. Presently, the species has been collected from Puharda (700m). The chromosome number in presently studied species is confirmed from presence of seven bivalents at metaphase I. The present chromosome count of $n=7$ confirms to the previous reports of $2 \mathrm{n}=14$ from India (Shani and Das 1988) and outside India (Fernandes and Queiros 1978). The course of meiosis is normal with high pollen fertility $(97.53 \%)$.

Vicia bithynica (L.) L.: It is a climber or scrambling annual herb. The leaflets are 1-3 paired with branched tendrils. The flowers are 1-3 with very short to long peduncles and whitish in colour. The fruits are 4-8 seeded. The presently worked out species has been collected from Boh which is located at an altitude of $1,900 \mathrm{~m}$. During meiotic course, seven bivalents are clearly observed at metaphase I. The present diploid chromosome count confirms to the previous reports of $2 n=14$ from India (Raina and Bisht 1988) and outside India. The species is found to have normal meiotic course with high pollen fertility $(95.70 \%)$.

Vicia hirsuta (L.) Gray: It is a trailing or climbing, annual herb which grows as weed in wheat fields during winter. The leaves are paripinnate having 3-10 pairs of leaflets which are linear-oblong and glabrous. The pods are rhomboid and 1-2 seeded. Presently worked out species has been collected from Rait located at an altitude of $700 \mathrm{~m}$. During meiosis six bivalents are clearly observed 
at metaphase I. The present chromosome number for the species is reported to be diploid level in conformity with the earlier reports of $2 n=12$ (Sareen and Trehan 1976, 1977). Subsequent course of meiosis is normal with high pollen fertility $(98.42 \%)$.

Vicia tetrasperma (L.) Schreb.: It is an annual, glabrous herb. The flowers are pale-blue coloured. The pods are flat, oblong and 4-5 seeded. The presently worked out species has been collected from Ranhear located at $850 \mathrm{~m}$ altitude. The meiotic course of the species depicts the presence of seven bivalents at metaphase I and confirms the earlier reports of $2 n=14$ (Probatova 2006, Bir and Kumari 1981). Subsequent course of meiosis is normal with high pollen fertility $(98.80 \%)$.

FAMILY: MALVACEAE Malvastrum coromandelianum $L$. Garcke: It is a common weed, with erect stem. The leaves are ovate, serate and hairy. It bears solitary, axillary orange-yellow coloured flowers. The species has been collected from Rehlu located at an altitude of $800 \mathrm{~m}$. The meiotic studies of the species reveals the presence of 12 bivalents at metaphase I. It confirms to the previous reports of $2 n=24$ (Krishnappa and Munirajappa 1980). The species is found to have normal meiotic course with high pollen fertility $(92.30 \%)$.

Malva neglecta Wallr: It is an annual plant with erect stellate pubescent stem. The leaves are ovate-orbicular, 5-6 lobed. Flowers are pale-pink coloured. The presently worked out species has been collected from Suliali located at $1,400 \mathrm{~m}$ altitude. During meiotic course, 21:21 distribution of chromosomes is observed at anaphase I . The present chromosome count is in line with the previous reports from India and outside India (Khatoon and Ali 1993). The species is found to have normal meiotic course with high pollen fertility $(93.00 \%)$.

FAMILY: ONAGRACEAE Epilobium alpinum L.: It is a perennial herb with entire or few toothed leaves. The flowers bear four pink notched petals. The present accession has been collected from Bara gran located at 3,000 m altitude. The meiotic course of the species reveals the haploid chromosome number $n=18$ at metaphase I conforming the earlier reports of $2 n=36$ from India and outside India. The course of meiosis is normal with high pollen fertility (91.20\%).

FAMILY: POACEAE Alopecurus nepalensis Trin. ex Steud.: It is characterised by either absence or short awns which are much shorter than the lemma. The spikelets are 2.75-3.00 $\mathrm{mm}$ long with lemma projecting $0.5 \mathrm{~mm}$ beyond tip of glumes. The glumes are glabrous on sides. The presently worked out species has been collected from Pohara located at an altitude of $800 \mathrm{~m}$. The meiotic course of the species shows equal distribution of 21:21 chromosomes at anaphase I. The present chromosome count is in conformity with the previous reports from India (Bir and Sahni 1987) and outside India. The course of meiosis is normal with high pollen fertility (94.67\%).

Capillipedium assimile (Steud.) A. Camus: It is an erect perennial herb often with decumbent base. The inflorescence is form of racemes with 2-6 spikelets. The collection of the presently studied species has been made from Palampur situated at an altitude of $2,000 \mathrm{~m}$. The presently worked out species shows the equal distribution of 10:10 chromosomes at A-I and confirms to the previous report of $2 n=20$ (Mehra 1982). The species is found to have abnormal meiotic course with the presence of cytomixis and chromatin stickiness at metaphase I resulting into reduced pollen fertility $(69.30 \%)$.

Dactylis glomerata $L$. It is characterized by its definitely awned and more acuminate lemmas with tufted, triangular flower heads forming a panicle. The present species has been collected from Lohardhari situated at an altitude of $2,600 \mathrm{~m}$. During meiotic course, seven bivalents have been observed at metaphase I stage which is in conformity with the earlier reports of $2 \mathrm{n}=14$ (Koul and Gohil 1990). The species is found to have abnormal meiotic course due to spindle malfunctioning resulting into late disjunction of bivalents and reduced pollen fertility (73.67\%).

Dichanthium annulatum (Forssk.) Stapf: It is perennial herb rooting at nodes. It has subimbricate arrangement of spikelets. Joints and pedicels are thick, without a transluscent furrow. The presently worked out species has been collected from Andretta situated at an altitude of 1,200 $\mathrm{m}$. The meiotic studies reveal the presence of 20 bivalents which is in line with the previous reports from India (Bir and Singh 1983) and outside India (Harlan et al. 1958). The course of meiosis is abnormal showing cytomixis at diakinesis $(4.00 \%)$, cytomictic channels, laggards at anaphase I (2.60\%) and abnormal microsporogenesis resulting into reduced pollen fertility (67.54\%).

Digitaria adscendens (Kunth) Henrard: It is characterized by spikelets elliptic-lanceolate, with 5-7 nerves visible on lower lemma. The upper glume is half as long as the spikelet or longer. Spikelets present without spreading hairs. The species has been collected from Ranhear situated at an altitude of $850 \mathrm{~m}$. During meiotic course, 36 bivalents have been observed at metaphase I confirming the earlier reports of $2 n=72$ (Khosla 1972; Bir and Sahni 1983). The course of meiosis is normal resulting into high pollen fertility $(94.32 \%)$.

Eleusine indica (L.) Gaertn.: It is an annual plant with slender spikes, decumbent and glabrous at base; lying prostrate on wet fields as a weed. The collection of the presently worked out species has been made from 
Macleodganj located at $1,900 \mathrm{~m}$ altitude. During meiotic course, nine bivalents have been observed at diakinesis conforming the earlier reports of $2 \mathrm{n}=18$ (Mehra et al. 1968). It shows normal meiotic course with high pollen fertility $(92.10 \%)$. The common occurrence of diploid $(2 \mathrm{n}=18)$, tetraploid $(2 \mathrm{n}=36)$ and hexaploid $(2 \mathrm{n}=54)$ cytotypes have also been reported by some workers. Besides, India also shows a single report of $2 n=16$.

Koeleria macrantha (Ledeb.) Schult.: It is a perennial and tuft forming bunch grass. The inflorescence is cylindrical and tapering towards the tip. The collection of the species has been made from Lohardhari located at 2,600 m altitude. During meiotic course, seven bivalents have been counted at metaphase I. It is in conformity with the earlier reports from India and outside India (Frey 1993, Arnow 1994). It shows normal meiotic course resulting into high pollen fertility (98.45\%).

Lolium remotum Schrank: It is characterised by upper glume reaching nearly to or exceeding the uppermost lemma, florets elliptic to ovate, spikelets turgid and awnless having lemmas $3-4 \mathrm{~mm}$ long. The species has been collected from Bara gran situated at $3,000 \mathrm{~m}$ altitude. The meiotic study of the species reveals the presence of seven bivalents at metaphase I which is in conformity with the previous reports from India (Malik and Thomas 1966) and outside India . Further the course of meiosis is abnormal showing cytomixis between different PMCs $(5.86 \%)$, laggards at telophase I $(4.84 \%)$ and micronuclei at tetrad stage resulting into reduced pollen fertility $(65.20 \%)$.

Pennisetum alopecuroides (L.) Spreng.: It is a perennial herb with erect culm. The leaf blades are either erect or drooping and flat. The presently worked out species has been collected from Daadh located at an altitude of $1,400 \mathrm{~m}$. The meiotic study of the species reveals the 18:18 distribution of chromosomes at anaphase I and confirms the previous report of $2 n=36$ from India (Sinha et al. 1990) and outside India. The course of meiosis is abnormal showing laggards at anaphase I resulting into reduced pollen fertility $(75.20 \%)$.

Phacelurus speciosus (Steud.) C.E. Hubb.: The racemes are present at top of the peduncle. The lower glume of the pedicelled spikelet is keeled, prolonged into an awn-like mucro. It is collected from Lohardhari situated at $2,600 \mathrm{~m}$ altitude for the present study. The presently worked out species shows 30:30 distribution of chromosomes at anaphase I and confirms to the previous report of $2 n=60$ from India and outside India. The course of meiosis is abnormal with presence of laggards at anaphase I (4.80\%), chromatin stickiness $(12.42 \%)$ and unoriented bivalents at metaphase I resulting into reduced pollen fertility $(67.80 \%)$.
Poa annua L.: It is an annual winter grass with simple erect culms. Spikelets oblong, lemmas broadly ovate, acute, keel and lateral nerves ciliate, back glabrous. The species has been collected from Jawala Ji situated at an altitude of $5,50 \mathrm{~m}$. The meiotic study of the species reveals the presence of seven bivalents at metaphase I conforming the earlier report of $2 n=14$ from India (Mehra and Sunder 1969) and outside India. The previous reports shows the existence of $2 \mathrm{x}, 3 \mathrm{x}, 4 \mathrm{x}, 6 \mathrm{x}$ cytotypes. The course of meiosis is normal resulting into high pollen fertility $(98.00 \%)$.

Pogonatherum crinitum (Thunb.) Kunth: The spikelets are upto $2 \mathrm{~mm}$ long. The callus hairs are also upto $2 \mathrm{~mm}$ long. Lower floret is either sterile or obsolete and upper floret having 1 or rarely 2 stamens. The presently worked out species has been collected from Nagrota situated at an altitude of $9,00 \mathrm{~m}$. During meiotic studies, ten bivalents have been observed at metaphase I conforming the earlier report of $2 n=20$ from India (Christopher 1978) and outside India. Subsequently the course of meiosis is normal with high pollen fertility $(91.50 \%)$.

Polypogon monspeliensis (L.) Desf.: It is a weed of cultivated fields as well as near water bodies. It is characterized by having awns $5-9.75 \mathrm{~mm}$ long, which are 2-3 times the length of the glumes. Presently worked out species has been collected from Bandla situated at an altitude of $1,600 \mathrm{~m}$. The meiotic study of the species reveals 21 bivalents at metaphase I and is in conformity with the previous reports from India (Koul and Gohil 1991) and outside India. The course of meiosis is normal and resulting into high pollen fertility (94.87\%).

Setaria glauca (L.) P. Beauv.: It is characterized by spikecylindrical; spikelets $3 \mathrm{~mm}$ long and upper lemma coarsely rugose, boat shaped, slightly keeled. It is collected from Dehra situated at altitude of $5,50 \mathrm{~m}$. The species shows 18:18 distribution of chromosomes at anaphase I. the present report of $n=36$ at tetraploid level confirms the earlier reports from India (Mehra and Remanandan 1973) and outside India. The species is based on $\mathrm{x}=9$ which is also known to exist at aneuploidy as well as polyploidy levels $(2 \mathrm{n}=28,35,38,44,54,72)$. The species is found to have normal meiotic course with high pollen fertility $(96.90 \%)$.

Setaria tomentosa (Roxb.) Kunth: It is characterized by its annual habit; narrow panicle and spikelets crowded or loosely scattered, $2 \mathrm{~mm}$ long. Presently the species has been collected from Dharamshala situated at an altitude of $1,800 \mathrm{~m}$. During meiotic course, 18 bivalents have been observed at metaphase I conforming the previous reports of $2 n=36$ except for reports of $2 n=18$ (Sindhe 1977) and $2 n=38$ (Bir and Singh 1983). The course of meiosis is normal resulting into high pollen fertility (91.55\%). 
FAMILY: RANUNCULACEAE Ranunculus hyperboreus Rottb.: It is a creeper on moist ground. The leaves are three lobed with base rounded or cunneate. Flowers are yellow coloured. Presently the species has been collected from Multan situated at an altitude of $2,300 \mathrm{~m}$. Meiotic studies of the species shows presence of 14 bivalents at Diakinesis. Earlier reports reveals the existence of $2 n=24$ (Sokolovskaya 1968), 2n=28 (Rani et al. 2011), 2n=32 (Zhokova 1982; Malakha 1990), and 2n=64 (Mosquin and Hayley 1966). The species is found to have abnormal meiotic course with cytomixis at Prophase (14.78\%), laggards at telophase I $(8.00 \%)$ and micronuclei at tetrad stage leading to low pollen fertility $(62.78 \%)$.

FAMILY: ROSACEAE Pyrus pashia Buch.-Ham.ex D. Don: It is a medium sized, deciduous tree. Leaves are ovate-glabrous. Flowers are white coloured having glabrous pedicel. Presently worked out species has been collected from Multan situated at an altitude of 2,300 m. The meiotic course of the species shows equal distribution of 17:17 chromosomes at anaphase I and confirms the previous reports (Chen 1993). The meiotic course is normal with high pollen fertility $(82.00 \%)$.

Rosa macrophylla Lindl.: It is an erect deciduous shrub with dark red or purple stems. He leaves are imparipinnate having 7-11 leaflets which are elliptical or ovate. Flowers are pink coloured. The collection of the species has been made from Ranhear situated at an altitude of $850 \mathrm{~m}$. Meiotic study of the species reveals the presence of seven bivalents at Diakinesis and confirms to the previous reports of $2 n=14$ from India (Sandhu and Mann 1989) and outside India. Meiotic course is normal with high pollen fertility $(92.40 \%)$.

Rubus ellipticus $S m$. It is an evergreen shrub with prickly and short lived stems. Flowers are white coloured with fruits orange and drooping. The species has been collected from Ranhear situated at $850 \mathrm{~m}$ altitude. Meiotic study reveals the presence of 7 bivalents at metaphase I which is in conformity with the previous reports from India (Kapil et al. 1989) and outside India. The species is found to have normal meiotic course resulting in slight pollen sterility $(80.22 \%)$.

ACKNOWLEDGMENTS The authors are thankful to UGC, New Delhi for financial assistance under DRS-SAP II, ASIST programme and to DST for grant under FIST programme. Ms. Kuljit Kaur is also grateful to UGC for providing a fellowship under Rajiv Gandhi National Fellowship Scheme. Thanks are also due to the Head of Department of Botany, Punjabi University, Patiala for providing the necessary laboratory and library facilities.

\section{Literature Cited}

Ahluwalia, K. S. 1952. Medicinal plants of Kangra Valley. Indian For. 78: 188-194.

Arnow, L. A. 1994. Koeleria macrantha and K. pyramidata (Poaceae): Nomenclatural problems and biological distinctions. Syst. Bot. 19(1): 6-20

Bairiganjan, G. C. and Patnaik, S. N. 1989. Chromosomal evolution in Fabaceae. Cytologia 54: 51-64.

Bir, S. S. and Sahni, M. 1983. SOCGI plant chromosome number reports-I. Journ. Cytol. Genet. 18: 58-59.

Bir, S. S. and Singh, C. 1983. SOCGI plant chromosome number reports - I. Journ. Cytol. Genet. 18: 60-61.

Bir, S. S. and Chauhan, H. S. 1990. SOCGI plant chromosome number reports-X. Journ. Cytol. Genet. 25: 322-323.

Bir, S. S. and Sahni M. 1983. SOCGI plant chromosome number reports - I. Journ. Cytol. Genet. 18: 58-59.

Bir, S. S. and M. Sahni. 1987. Chromosomal and morphological variations in grasses of Punjab. Joyrn. Cytol. Genet. 22: $12-22$

Chen, R. Y. 1993. (editor), Chromosome atlas of Chinese fruit trees and their close wild relatives. Chromosome Atlas Chin. Princ. Econ. Pl. 1.

Christopher, J. 1978. Studies on the cytology and phylogeny of South Indian grasses IV. Sub-family Panicoideae; tribes Andropogoneae and Maydeae. Cytologia 43: 273 387

Faruqi, S. A., H. B. Quraish and Halai, N. 1979. Chromosome numbers and morphological I I characteristics of some Andropogoneae of Pakistan. Cytologia 44: 585-605.

Fernandes, A. and Queiros, M. 1978. Contribution a la connaissance cytotaxinomique des Spermatophyta du Portugal. IV. Leguminosee (Suppl. 3). Bol. Soc. Brot., sér. 2, 52: 79-164.

Frey, L. 1993. Taxonomy, karyology and distribution of selected genera of tribe Aveneae (Poaceae) in Poland: III. Koeleria. Fragm. Florist. Geobot. Suppl. 2(1): 251-278.

Jaretzky, R. 1932. Beziehungen zwischen Chromosomenzahl und Systematik bei den Cruciferen. Jahrb Wiss Botanik 76: 485-527.

Jeelani, S. M., Kumari, S. and Gupta, R. C. 2011. IAPT/IOPB chromosome data 12. Taxon 60 (6): 1784-1796.

Kapil, M., Mann, S. K. and Sandhu P.S. 1989. Cytological studies in Rubus ellipticus Sm. Cell Chrom. Res. 12: 1921.

Kapur, S.K. 1993. Ethno-medico plants of Kangra Valley (Himachal Pradesh) Ibid. 17: 395-408.

Khatoon, S. and Ali, S. I. 1993. Chromosome Atlas of the Angiosperms of Pakistan. Department of Botany, University of Karachi, Karachi.

Khosla, P. K. 1972. In IOPB chromosome number reports XXXV. Taxon 21: 161-166.

Koul, K. K. and Gohil, R. N. 1987. SOCGI plant chromosome number reports - IV [i.e., V]. J. Cytol. Genet. 22: 161-162.

Koul, K. K. and Gohil, R. N. 1990. Cytological studies on some Kashmir grasses-V. Dactylis glomerata Linn. J. Cytol. Genet. 25: 74-77.

Koul, K. K. and Gohil, R. N. 1991. Cytogenetic studies on some Kashmir grasses. VIII Tribe Agrostideae, Festuceae and Paniceae. Cytologia 56: 437-452.

Krishnappa, D. G. and Munirajappa. 1980. In Chromosome number reports LXVIII. Taxon 29:535-536.

Kumari, S. and Bir, S. S. 1990. Karyomorphological evolution in Papilionaceae. J. Cytol. Genet. 25: 173-219.

Malakha, E. V. 1990. Chromosome numbers in some species of the genera Ranunculus and Batrachium (Ranunculaceae) from the flora of the Soviet far east. Bot. Žhurn. (Moscow and Leningrad) 75: 121-122.

Malik, C.P. and Thomas, P.T. 1966. Karyotypic studies in some Lolium and Festuca species. Caryologia 19: 167196.

Mehra, P.N. and Remanandan, P. 1973. Cytological investigations on W. Himalayan Pooideae. Cytologia 38: 237-258.

Mehra, P.N. and Sunder, S. 1969. Cytological studies in the North Indian Grasses. Part II. Res. Bull. Panjab. Univ., Sci. 20: 503-539. 
Mehra, P.N., Khosla, P.K., Kohli, B.L. and Koonar, J.S. 1968. Cytological studies in North Indian Grasses. I. Res. Bull. Panjab Univ., Sci. 19: 157-230.

Mehra, P. N. 1982. Cytology of East Indian grasses. ý.

Probatova. 2006. Chromosome numbers of plants of the Primorsky Territory, the Amur River basin and Magadan region. Bot. Žhurn. (Moscow and Leningrad) 91(3): 491509.

Raina, S. N. and Bisht, M. S. 1988. DNA amounts and chromatin compactness in Vicia. Genetica 77: 65-77.

Rani, S., Kumari, S. and Gupta, R. C. 2011. IAPT/IOPB chromosome data 12. Taxon 60(6): 1784-1796.

Sandhu, P. S. and Mann, S. K. 1989. SOCGI plant chromosome number reports - VIII. J. Cytol. Genet. 24: 179-183.

Sareen, T. S. and Trehan, R. 1977. Cytological studies in some Papilionaceae. Proc. Indian Sci. Congr. Assoc. 64: 156.

Shani, D. K. and Das, A. 1988. Meiotic irregularities and chiasma frequency in four species of Lathyrus. Proc. Indian Sci. Congr. Assoc. 75(3-VI): 217.

Sharma, B. and Maheshwari, S. 2005. Traditional medical practices of Gaddi tribes of Kangra district, Himachal Pradesh. Indian J. of Trad. Knowl. 4(2): 169-172.

Sidhu, M. and Bir. S. S. 1983. Karyological studies on weeds on cultivable lands in Punjab, India. Trop. Plant Sci. Res.
1: $1-13$.

Sindhe, A.N.R. 1977. In IOPB chromosome number reports LVI. Taxon 26: 257-274.

Sinha, R. R. P., Bhardwaj A. K. and Singh R. K. 1990. SOCGI plant chromosome number reports-IX. J. Cytol. Genet. 25: $140-143$

Sood, R.P., Kalia, N.K. and Sobti, S.N. 1982. Scope for development of phytochemical and essential oil industry in Palampur area (Kangra Valley). Nagarjun 30-34.

Uniyal, M. R. and Chauhan, N. C. 1971. Medicinal plants of Uhl Valley in Kangra Forest Division, Himachal Pradesh. J.Res.Indien Med.Res. 6: 287-299.

Uniyal, M. R. and Chauhan, N. C. 1973. Traditionally Important medicinal plants of Kangra Valley in Dharamshala Forest circle, H.P. Ibid. 8: 7-85.

Uniyal, S. K., Kumar, A., Brij, Lal and Singh, R. D. 2006. Quantitative assessment and traditional uses of high value medicinal plants in Chhota Bhangal area of Himachal Pradesh, Western Himalaya. Current Science 91(9): 12381242.

Zhukova, P. G. 1982. Chromosome numbers of some plant species of north-eastern Asia. Bot. Zhurn. SSSR 67 (3): 360-365. 

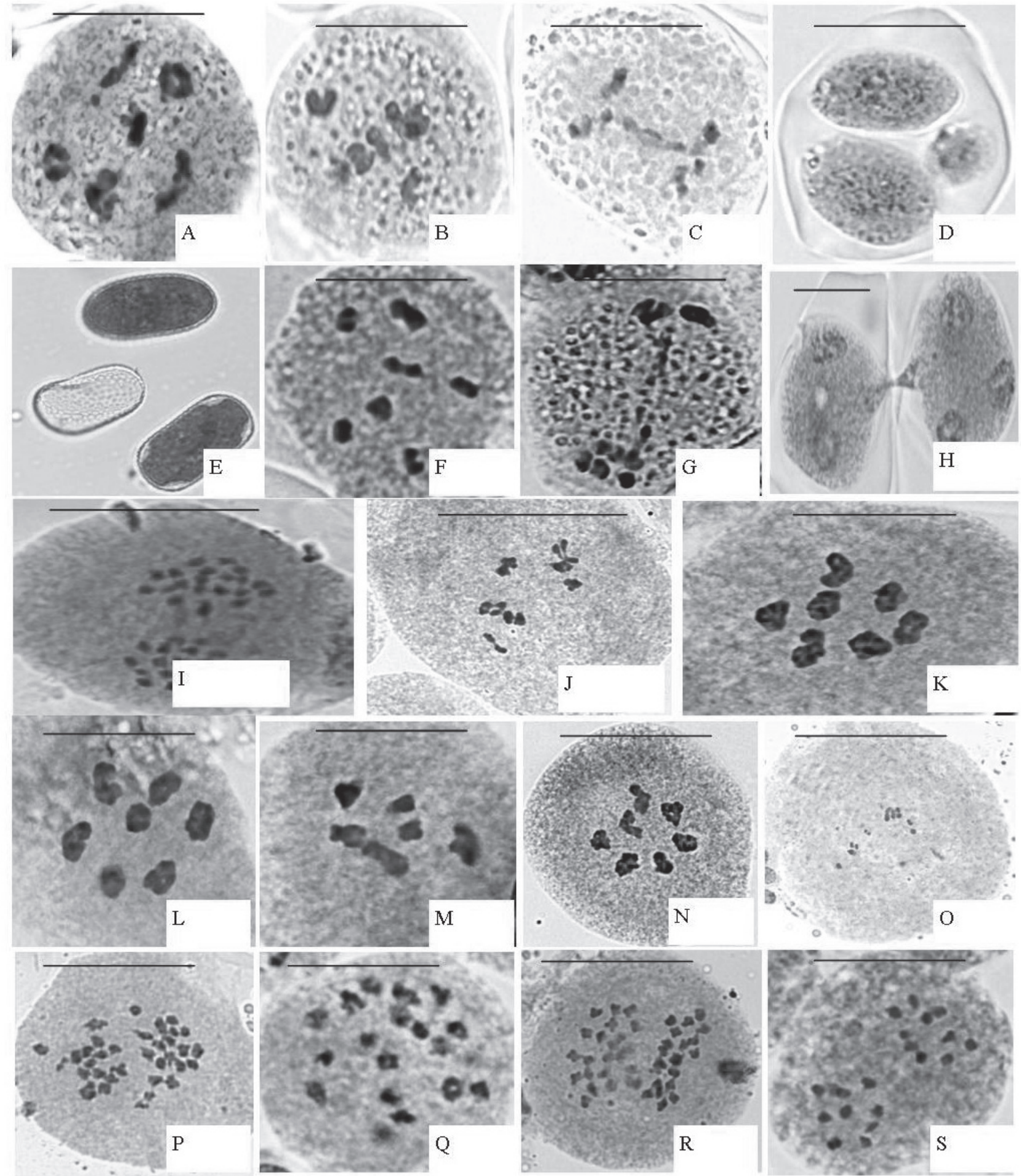

Fig. 1. Meiotic chromosomes of: A-E. Impatiens scabrida $(\mathrm{n}=6)$. A. PMC at M-I. B. PMC showing unoriented bivalents at M-I. C. Chromatin bridge at A-I. D. Dyad with micronucleus. E. Sterile and fertile pollen grains. F-I. Sysimbrium strictum $(\mathrm{n}=7)$. F. PMC at metaphase I. G. Chromatin bridge at anaphase I. H. PMCs showing cytomixis at telophase II. I. Aeschynomene indica $(\mathrm{n}=20)$. PMC at anaphase I. J. Desmodium gangeticum $(\mathrm{n}=11)$. PMC at metaphase I. K. Lathyrus aphaca $(\mathrm{n}=7)$. PMC at metaphase I. L. Vicia bithynica $(\mathrm{n}=7)$. PMC at metaphase I. M. Vicia hirsuta $(\mathrm{n}=6)$. PMC at M-I. N. Vicia tetrasperma $(\mathrm{n}=7)$. PMC at M-I. O. Malvastrum coromendelianum $(\mathrm{n}=12)$. PMC at M-I. P. Malva neglecta $(\mathrm{n}=21)$. PMC at M-I. Q. Epilobium alpinum (n=18).PMC at M-I. R. Alopecurus nepalensis $(\mathrm{n}=21)$. PMC at anaphase I. S. Capillipedium assimile $(\mathrm{n}=10)$. PMC at anaphase I. Bar $=10 \mu \mathrm{m}$. 


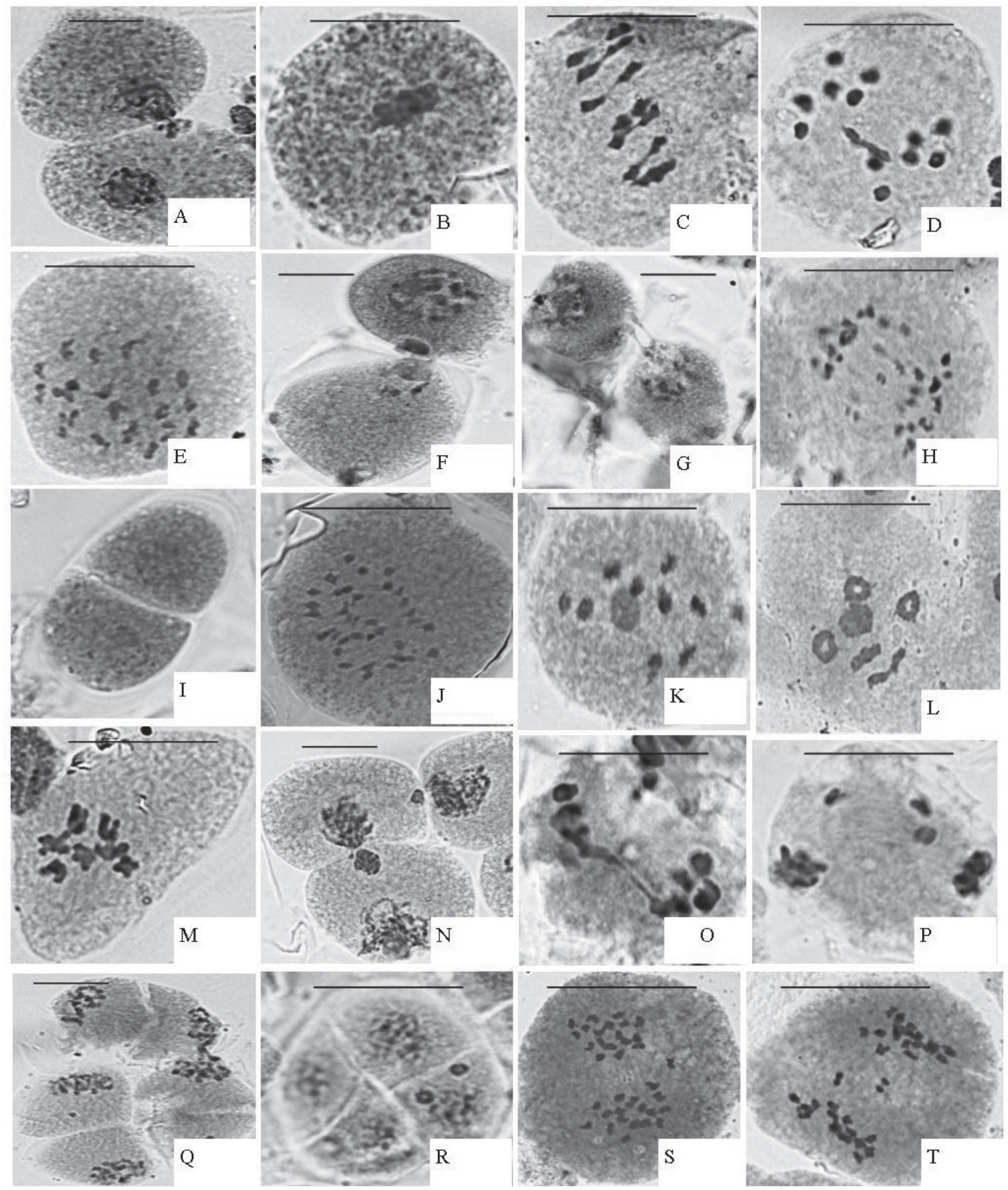

Fig. 2. Meiotic Chromosomes of: A-B. Capillipedium assimile. A. PMCs showing cytomoxis. B. Chromatin stickiness at metaphase I. C-D. Dactylis glomerata $(\mathrm{n}=7)$. C. PMC at metaphase I. D. Late disjunction of bivalent at anaphase I. E-I. Dichanthium annulatum (n=20). E. PMC at M-I. F. PMCs showing chromatin transfer. G. Cytomictic channels. H. Laggards at anaphase I. I. Dyad. J. Digitaria adscendens $(\mathrm{n}=36)$. PMC at metaphase I. K. Eleusine indica $(\mathrm{n}=9)$. PMC at Diakinesis. L. Koeleria macrantha $(\mathrm{n}=7)$. PMC at metaphase I. M-R. Lolium remotum $(\mathrm{n}=7)$. M. PMC at metaphase I. N. PMCs showing cytomixis at prophase I. and metaphase I. O. Bridge at anaphase I. P. Laggard at telophase I. Q. Cytomixis at telophase II. R. Tetrad with micronuclei. S-T. Pennisetum alopecuroides $(n=18)$. S. PMC at anaphase I. T. Laggards at anaphase I. $\mathrm{Bar}=10 \mu \mathrm{m}$. 

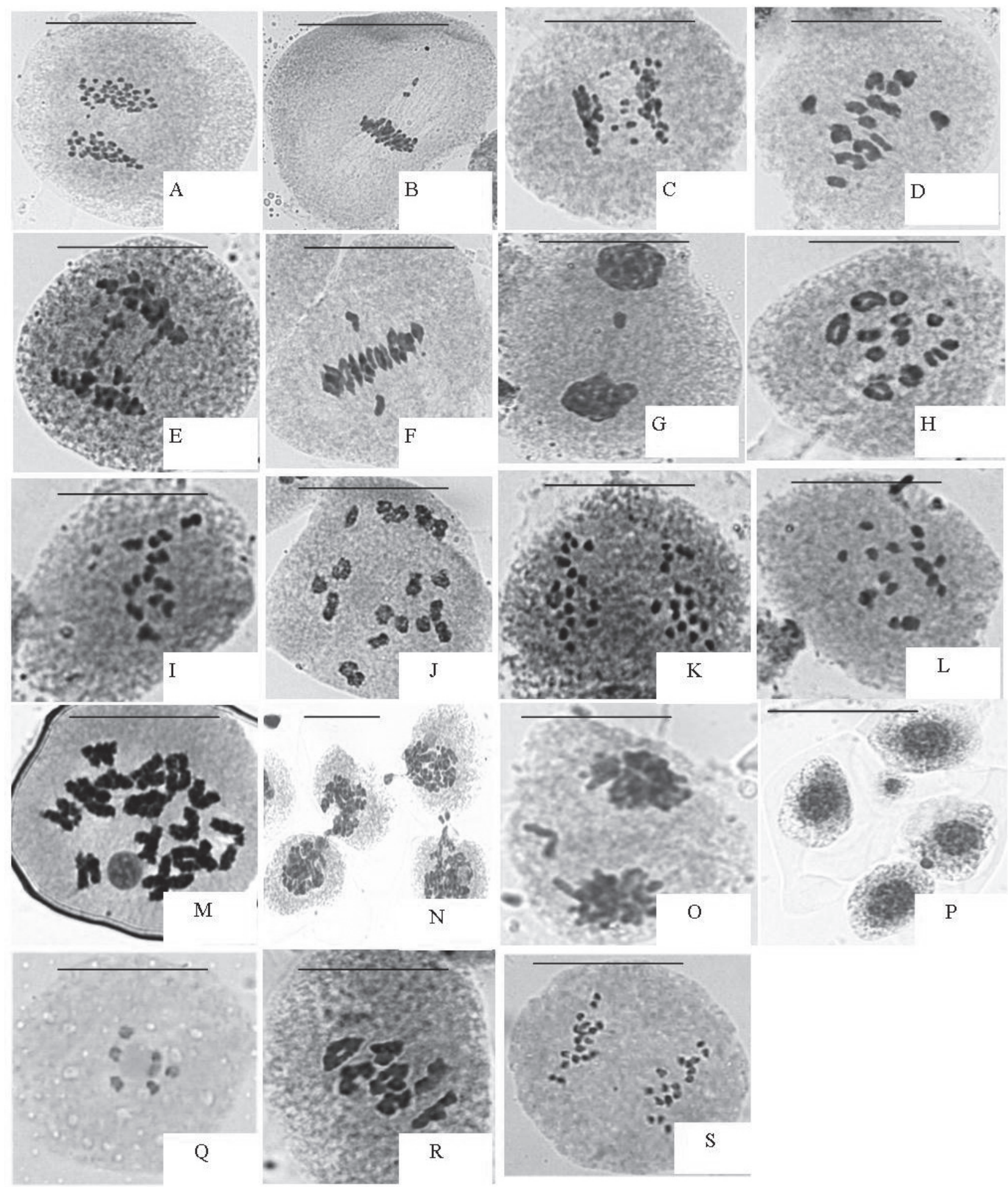

Fig. 3. Meiotic chromosomes of: A-C. Phacelurus speciosus $(\mathrm{n}=30)$. A. PMC at anaphase I. B. PMC showing unoriented bivalents and chromatin stickiness at metaphase I. C. Laggards at anaphase I. D-G. Phalaris minor (n=14). D. PMC at metaphase I. E. Chromatin bridge at anaphase I. F. Unoriented bivalents at metaphase I. G. Laggard at telophase I. H. Poa annua $(\mathrm{n}=14)$. PMC at metaphase I. I. Pogonatherum crinitum $(\mathrm{n}=10)$. PMC at metaphase I. J. Polypogon monspeliensis $(\mathrm{n}=21)$. PMC at metaphase I. K. Setaria glauca $(\mathrm{n}=18)$. PMC at anaphase I. L. Setaria tomentosa $(\mathrm{n}=18)$. PMC at metaphase I. M-P. Ranunculus hyperboreus $(\mathrm{n}=14)$. M. PMC at Diakinesis N. PMCs showing cytomixis. O. Laggard at telophase I. P. Micronuclei at Tetrad stage. Q. Rosa macrophylla $(\mathrm{n}=7)$. PMC at Diakinesis. R. Rubus ellipticus $(\mathrm{n}=7)$. PMC at metaphase I. S. Pyrus pashia $(\mathrm{n}=7)$. PMC at anaphase I. Bar $=10 \mu \mathrm{m}$. 